\title{
Church, mission and ethics. Being church with integrity
}

\begin{tabular}{|c|c|}
\hline $\begin{array}{l}\text { Author: } \\
\text { Wim Dreyer }\end{array}$ & \\
\hline $\begin{array}{l}\text { Affiliation: } \\
{ }^{1} \text { Department } \\
\text { History and } \mathrm{Cl} \\
\text { Faculty of The } \\
\text { University of } \\
\text { South Africa }\end{array}$ & $\begin{array}{l}\text { of Church } \\
\text { nurch Polity, } \\
\text { ology, } \\
\text { Pretoria, }\end{array}$ \\
\hline $\begin{array}{l}\text { Research Proj } \\
\text { Registration: } \\
\text { Project Leade } \\
\text { Project Numb }\end{array}$ & $\begin{array}{l}\text { ect } \\
\text { r: W. Dreyer } \\
\text { er: } 77370920\end{array}$ \\
\hline $\begin{array}{l}\text { Description: } \\
\text { This research } \\
\text { project 'Practi } \\
\text { Ecclesiology', } \\
\text { Dreyer of the } \\
\text { Church Histor } \\
\text { Polity, Faculty } \\
\text { University of }\end{array}$ & $\begin{array}{l}\text { s part of the } \\
\text { cal } \\
\text { ff Dr Wim } \\
\text { Department of } \\
\text { and Church } \\
\text { of Theology, } \\
\text { retoria. }\end{array}$ \\
\hline $\begin{array}{l}\text { Correspondin } \\
\text { Wim Dreyer, } \\
\text { wim.dreyer@ }\end{array}$ & $\begin{array}{l}\text { g author: } \\
\text { up.ac.za }\end{array}$ \\
\hline $\begin{array}{l}\text { Dates: } \\
\text { Received: } 23 \\
\text { Accepted: } 14 \\
\text { Published: } 07\end{array}$ & $\begin{array}{l}\text { ung. } 2015 \\
\text { Nov. } 2015 \\
\text { June } 2016\end{array}$ \\
\hline $\begin{array}{l}\text { How to cite th } \\
\text { Dreyer, W., } 20 \\
\text { mission and e } \\
\text { church with in } \\
\text { HTS Teologies } \\
\text { Theological St } \\
\text { a3163. http:// } \\
\text { org/10.4102/l }\end{array}$ & $\begin{array}{l}\text { is article: } \\
16, \text { 'Church, } \\
\text { hics. Being } \\
\text { tegrity', } \\
\text { Studies/ } \\
\text { udies } 72(1) \text {, } \\
\text { dx.doi. } \\
\text { ts.v72i1.3163 }\end{array}$ \\
\hline $\begin{array}{l}\text { Copyright: } \\
\text { (c) 2016. The } \\
\text { Licensee: AOS } \\
\text { is licensed un } \\
\text { Creative Comr } \\
\text { Attribution Lic }\end{array}$ & $\begin{array}{l}\text { uthors. } \\
\text { S. This work } \\
\text { ler the } \\
\text { nons } \\
\text { ense. }\end{array}$ \\
\hline Read online: & \\
\hline 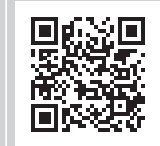 & $\begin{array}{l}\text { Scan this QR } \\
\text { code with your } \\
\text { smart phone or } \\
\text { mobile device } \\
\text { to read online. }\end{array}$ \\
\hline
\end{tabular}

This article is an exercise in Practical Ecclesiology. The author reflects on church, mission and ethics from historical, hermeneutical and strategic perspectives. Using the ecclesiology of Karl Barth as a point of departure, the author argues that the church needs to be church if it wants to be a credible witness to the Gospel of Jesus Christ. Integrity is essential if a church wants to be missional. Integrity means the church has to become what it already is, the body of Christ. This contribution is dedicated to Prof Graham Duncan, professor emeritus of church history (University of Pretoria), a man of integrity and dedicated to the missional calling of the church.

\section{Introduction}

'Christianity has an image problem' (Kinnaman 2007:11). Extensive empirical research indicates that $40 \%$ of young Americans between the age of 16 and 29 regard themselves as 'unchristian'. The main reason for their deconversion is a perception that the church cannot be trusted, lacks integrity and has lost its original purpose (Kinnaman 2007:15). Seen from this perspective, the church itself is the major contributor to deconversion and people leaving the church. ${ }^{1}$

It is no different in South Africa. On the front page of the Pretoria News Ilanit Chernick $(2015: 1)$ reports that the South African Commission for the Protection of Rights of Cultural, Religious and Linguistic Communities intends to root out what they call 'charlatan practices' of some pastors. It is the Commission's intention to start an empirical investigation of 'dangerous religious practices', such as pastors forcing congregants to eat grass, snakes or drink gasoline. People stop using medicine because faith healers tell them that 'holy water' (which they are selling) will cure them from HIV-Aids. Part of the Commission's investigation will entail considering which legal actions could be taken. The investigation will further look into the 'commercialisation of religion' which is based on the 'abuse of people's belief system'.

Many examples could be added to this. In fact, 'church-bashing' had become quite popular amongst journalists, often with good reason. Recently published literature, including empirical research, reveals a growing disillusionment with ecclesial practices and a disturbing picture of how churches could lose their way and become engrossed in things that bear little semblance to the life and teaching of Christ. Recurring themes could be summarised as follows:

- Institutionalism: More traditional churches are perceived to be obsessed with their own survival and the maintenance of the institutional aspects of the church (cf. Viola \& Barna 2008).

- Materialism: Some churches function as a commercial enterprise with stakeholders, directors, branding, franchising and huge revenue. Some of these 'churches' generate more than two hundred million dollars in revenue per annum and pastors with a million dollar salary are not uncommon. These churches' business practices, buildings and marketing strategies encapsulate the very essence of Western materialism (cf. Rah 2009).

- Sexual abuse: Küng (1968:28) points out that it is not uncommon for the media (and in movies) to depict the church as a 'place of evil'. Exposés of paedophilia and sexual abuse makes this abundantly clear.

- Fraudulent ministries: 'Healing ministries' proven to be fraudulent is quite common. Many documentaries and books proved this point. A quick search on the Internet shows close to a million postings on fraudulent healings. In some cases where patients stopped medical treatment, it led to their death (cf. Randi 1987).

1.In this contribution I do not intend to discuss the whole issue of declining church membership, which is of course much more complex than just an 'image problem' or a question of integrity. For a more detailed discussion of contributing factors to declining membership in the South African context, see Dreyer (2011). 
- Ideology: Too often in history the church became instrumental in legitimising and promoting ideology, political agendas and playing for power (cf. Boyd 2005). The history of South African churches in terms of apartheid is testament to this fact.

Church, mission and ethics have often been discussed. In the ecumenical movement and theology, ecclesiology is a central theme, often linked to mission and ethics, especially political and economic justice. The vast number of publications on these and related themes by various ecumenical organisations is quite remarkable (see for instance Faith \& Order 1990; 2005; Lodberg 1995; Reuver 2000; World Alliance of Reformed Churches 2010; World Council of Churches 2013).

Literature on missional ecclesiology often highlights the nature of the church and how it is translated into congregational praxis. In South Africa, Malan Nel is a leading theologian in this field. In a contribution titled 'Missionale integriteit en kontekstuele relevansie', he reflects on the church being missional with integrity ( $\mathrm{Nel} 2010)$. He points out that missional integrity rests on (1) the ability of the local congregation to be contextually (locally) relevant and (2) a self-understanding of being church as part of the Triune God's new creation and involvement in this world. It is quite clear that church, mission and ethics are inextricably woven together, a reality which the church sometimes forgets to its own detriment.

A definition of what is meant by 'integrity' is also necessary at the outset. In this contribution the focus is not on moral behaviour or ethics as such, but on the 'church being church'. In other words: It is about the church being whole, being what it is supposed to be. In Latin, 'integritas' has the meaning of an object being whole or in its original state. The object is not broken. The vase is not cracked or chipped. The integrity of the church has to do with the church being able to be church in terms of the essential nature of the church as proclaimed in Scripture. The church is the body of Christ, but has to continually become the body of Christ. Being what you are is real integrity. As such, ecclesial integrity is never something superficial, but an expression of the very essence of being church. Ethics come into play when we realise that the nature of the church should correlate with what the church does. Church, mission and ethics are facets of one single diamond. A continual process of transformation, of becoming what we are, results in the church being a church with integrity.

The church is not only facing an 'image problem', or challenges in terms of ethics or local relevance, but rather a real challenge to be church. The church does not need an image make-over; it is in direneed of fundamental transformation. Transformation could never be about window-dressing programmes or managing the future of the church. Transformation has to do with the fundamental nature of the church. When we reflect on the nature of the church as being holy and apostolic, the missional character and integrity of the church need to be regarded as important and interrelated issues.
A last introductory remark: This contribution is an exercise in Practical Ecclesiology (see Dreyer 2011). The multi-disciplinary methodology used in Practical Ecclesiology normally makes use of historical, hermeneutical, empirical and strategic perspectives. In this contribution the empirical perspective (for instance statistical analysis) is not utilised. The topic is discussed from historical, hermeneutical and strategic perspectives.

The history of the Christian church bears witness to the fact that ecclesial integrity is of the utmost importance. This is illustrated by two historical examples: The church in Corinth (early church history) and Karl Barth's reaction to the German Christian Movement (modern church history). This contribution concludes with some suggestions for the future.

\section{Historical perspective: The church in Corinth}

From the very beginning the church had to deal with the issue of integrity and its 'image' in society. One early example is the church in Corinth. Corinth was a city located in the north-east of the Peloponnesus. The city was often visited by travelling teachers, physicians and philosophers (Pauw 2012:1). The Corinthian people were susceptible to all kinds of ideas, as is clear from the Pauline letters. This led to group forming (1 Cor 1:11-12), spiritualism (2 Cor 10-13) and even a continued affinity to the mystery religions of the time (1 Cor 12:2).

Fifty years later the church in Corinth was still troubled by divisions, immoral behaviour and doctrinal arguments (see First Letter of Clement to the Corinthians [Goold \& Lake 1975]). According to Altaner (1951:73-74), Clement of Rome is mentioned by Origines and Eusebius as one of the co-workers of the apostle Paul. He was the third bishop of Rome after Peter. Tertullian writes in his De praescriptione haereticorum XXXII that he had been ordained in ministry by the apostle Peter (see Pauw 2012:2). Clement of Rome was held in such high esteem that the First Epistle of Clement to the Corinthians was included in the Codex Alexandrinus and regarded by many, that is, the Syrian Church, as canonical.

A group of Corinthian Christians (probably younger members of the church (see 1 Clement III/3) rejected the authority of the presbyters. We read in 1 Clement XLVII/6:

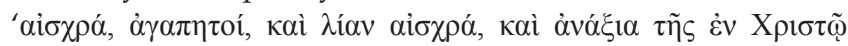

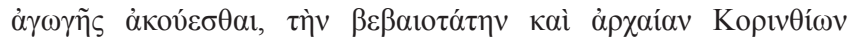

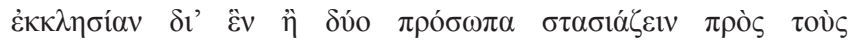
$\pi \rho \varepsilon \sigma \beta v \tau \varepsilon \dot{\varepsilon} \rho 0 u \varsigma . '$ The disgust with which Clement regarded the undermining of the presbyters' authority and position in the 'ancient church of Corinth' is clear in his repetitive use of

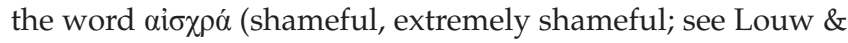
Nida 1989:6) in this passage. This conduct was not only detrimental to the church in Corinth, causing some members to lose faith (1 Clement XLVI/9), but also tarnished the reputation of the church of Corinth in the eyes of the general public. Non-Christians heard about the schism, divisions and conflict which led them to mock the church, the Christians in 
general and blaspheming the name of God (1 Clement XLVII/7; see also 1 Cor 10:32).

This situation was of utmost concern to the church in Rome and gave rise to the writing of the letter. It has a distinct paraenetic approach, admonishing those who were busy with unruly conduct to repent and follow the example of holy people in the Bible and, indeed, Jesus Christ himself. It is clear that the First Letter of Clement to the Corinthians is structured with a very specific paraenetic objective in mind, namely the good reputation of the church in Corinth which is destroyed by sedition and schism (1 Clement I-III), which in turn leads to a lack of credibility and inability to witness to the world.

Early Christianity maintained certain social values not only as obedience to God, but also as part of their witness to outsiders and part of their missional activities. Values like charity, mutual support, self-control and others drew people to Christianity (Schor 2009:478). It was not only the teaching of these values by the clerics which attracted people, but rather the way ordinary Christians gave practical and physical expression to Christian love (Dreyer 2012). We find this reflected in many early texts. Du Toit (2012) describes it as follows:

As the Christian message moved from its original Jewish home into Gentile surroundings, the first Christians became increasingly conscious of their non-Christian environment. They were obliged to responsibly position themselves and their ethos as Christians within this environment. (p. 1)

Paraenetic texts reflect (1) obedience to God; (2) early Christian ethos, and (3) a sensitivity towards outsiders, even if it is not explicitly mentioned.

Kotze (2013:2-3) is of the opinion that current research on paraenetic and protreptic texts uncritically maintains a dichotomous view of such texts. The words 'protreptic' and 'paraenetic' have acquired technical meanings and became the subject matter of separate research areas. She defines it as follows:

Mainstream definitions of protreptic and paraenetic revolve around communicative purpose and audience location: protreptic is characterised by the purpose to convert, paraenesis by the purpose to confirm belief or strengthen the resolve of the audience; the intended audience of protreptic literature is the not-yet-converted (outsiders) who have to be persuaded of the validity of a certain way of life, whilst paraenesis is aimed at an audience of the already converted (insiders) sharing the author's world view. (Kotze 2013:2)

Kotze comes to the conclusion that in ancient literature the two terms are almost consistently used interchangeably and synonymously. At the same time the texts categorised as being either protreptic or paraenetic more frequently display a mixture of characteristics ascribed to protreptic and paraenetic respectively than those of one type exclusively (Kotze 2013:3).

From this perspective, a paraenetic text such as 1 Clement also has a purpose to convert, although it is not explicitly spelled out. The intrinsic protreptic purpose of paraenetic texts becomes evident in certain passages, for instance 1 Clement I/ 2 where the admiration people (outsiders) had for the church in Corinth's virtue, faith, sobriety, hospitality and Christian gentleness is mentioned. These were the real Christian qualities which drew many people to the church and led to their conversion to the Christian faith.

This small historical excursion makes it clear that, from the earliest existence of the church there was a clear understanding of the interrelatedness between church, mission and an ethical (Christian) way of life. This could be traced back to Jesus himself. In the Sermon on the Mount (Mt 5) Jesus teaches his disciples to act in such a way that people would see their good works and glorify God.

\section{Hermeneutical perspective: Karl Barth's understanding of what it means to be church}

Ever since the early church, through medieval and reformation history into modern times, the church struggled with issues of integrity. In modern history Karl Barth was the one theologian who helped the church to understand that ecclesial integrity has primarily to do with the correlation between the essential nature of the church and the manifestation of the church in everyday life. In short: What the church is should become visible in what the church does.

Barth's own life was an example of this basic principle, for instance his criticism of Nazism before World War II, as well as the church's inability to fulfil its prophetic role in society. In the early 1930s Barth found himself at the centre of church politics in the face of gigantic stupidity, lying, brutality and fear (Webster 2000:8). Despite much opposition, Barth placed the church under the piercing light of the Word, fiercely criticising the church's loss of moral direction.

On 30 January 1933 Adolf Hitler was named Chancellor of Germany. He immediately took control by increasing the powers of the Gestapo and eliminating all real opposition to his vision of a unified, one-party state. During 1934 Barth was involved in the drafting of the Barmen Declaration opposing the German Christian Movement. In a time when civil religion was common and the church depended on a very powerful state for funding, his actions were radical, controversial and dangerous. His uncompromising criticism of developments in Germany and refusal to take the oath of loyalty to Hitler, led to his dismissal from his teaching post in Bonn and he had to return to Switzerland (Busch 1998:38-40). He started teaching at Basel University and worked for the rest of his life on his Church Dogmatics.

Barth's sharp ecclesiological insight and criticism of the church is still relevant. The context might have changed, but the fundamental question remains: How can the church be church with integrity? This is a question concerning the nature of the church with direct implications for the ethical behaviour and actions of the church (Bender 2005:5-7). 
On 22 July 1933, just before important church elections in Bonn which would determine the direction of the German church, Barth addressed a meeting with a passionate plea not to jeopardise the freedom of the Gospel by voting for a direction which would enslave the church to nationalistic ideals (Barth 1933:7). He pointed out that neither nature, nor history or culture

macht die Kirche zur Kirche und nicht von daher ist die Kirche als Kiche zu verstehen. Evangelium heist ja nicht: der Mensch für Gott!, sondern ganz und gar und allein: Gott für den Menschen. Will die Kirche Kirche sein und bleiben, dann muss sie zäh und eiferfüchtig über dieser Verkündigung wachen als über ihrem Wesen ... (Barth 1933:6-7)

If 'the church wants to be church' it has to protect the freedom of the Gospel which proclaims Jesus Christ as the only head and King of the church.

Busch (1998:255) points out that Barth does not use the word 'bleiben' in the way which was common at the time. In Germany there were those who believed that the church should remain church, with the implication that all was well and that there was no reason to change. The tradition, the dependence of the church on state support, the organic unity between the German people (Volk) and the church, as well as the annexation of the church for political ideals (Barth 1933:8) should not change. The church should stay the same if it really wanted to be church.

We must understand what Barth had in mind. In the expression 'the church must be church' the first reference to 'church' had to do with the 'credo ecclesiam', the church we believe in. The second had to do with the church that manifested empirically. If there is a discrepancy between the visible and invisible church, it calls for reformation according to the Word of God (Barth 1933:10-11). In other words: The continued reformation of the church is reformation according to the Word of God with the purpose to 'be church' in accordance with the Gospel and not the sort of renewal (Erneuerung) which people and politicians are expecting.

The challenge facing the church is to 'be church' (Busch 2004:246-247) and to 'stay church' as the body of Christ, the community of the Spirit and the people of God (cf. Bender 2005). To be a church with integrity means 'to be church'; to make the invisible visible, to be what God meant it to be. Integrity implies a deep consciousness of the true nature of the church and continual reformation of the church to be what it is.

We should understand that nothing we do could establish or constitute the church. The church exists because of God's actions. If we are under the impression that we can improve or complete the church which already exists through the power of God, we are mistaken. The challenge is simply to 'be church'. However, we should not be misled by the simplicity of this formulation.

How should the una sancta ecclesia manifest in this world? Barth spent much time on the exposition of the four attributes of the church, what it means to be the one and holy, catholic and apostolic church. Bender (2005) writes:

Barth's dialectical understanding of the church as both an invisible and visible reality, an event of the Holy Spirit and a historical entity, leads naturally to his dialectical understanding of the marks of the church. (p. 181)

\section{Barth (CD IV.1:669) writes:}

For that reason the visible and invisible church are not two churches ... The one is the form and the other the mystery of one and the self-same church. The mystery is hidden in the form, but represented and to be sought in it.

This implies that the four attributes of the church are not only applicable to the eternal and invisible church of the confession, but also to the local congregation or church which manifests empirically in history.

In an era where ecumenical organisations often defined church unity in terms of organisational unity, it is important to note that Barth is of the opinion that the unity of the church is not found in overarching ecclesiastical authority, political arrangement or structure, but in the one Lord who calls the community into existence and joins them together (Bender 2005:182). In that way, unity in diversity becomes possible.

Koffeman (2014:131-134) 'translates' the four attributes of the invisible church to quality markers of the visible church, following Barth and Dombois. As Koffeman (2014:19) explains, the attributes of the church and the everyday manifestation of the church should not be seen as opposites, but as complimentary to each other. A dualistic distinction between the visible and invisible church is no longer feasible. There is only one church. It requires of the 'visible church' to 'be church', to be what it is in Christ.

According to Koffeman, the quality marker 'integrity' relates to the church of which the confessions say that it is 'holy'. It has 'institutional consequences', that is, to be utterly reliable and trustworthy. The values and ethical behaviour of the church should be beyond reproach. With reference to Barth, Koffeman (2014:217) explains that the church is holy only because it is sanctified by Christ. The holiness of the church is often contradicted by sin, but also a gift from God nobody can take away from the church. From this perspective, the church could never exist in any other way as ecclesia semper reformanda.

Another important feature of Barth's approach to ecclesiology is the correlation between the being of Christ and the being of the church (Webster 2000:129). The church exists because Christ exists. In his Church Dogmatics (Barth 1956) Barth speaks of the church as the 'earthly-historical form of existence of Jesus Christ Himself' (Barth 1956:661; Bender 2005:198; Webster 2000:130).

This enigmatic expression of Barth can only be understood within the context of his rejection of the church as some institutionalised, cultural and historical organisation serving the needs of the people or the state. The church is not a 
religious society, but rather a new humanity reconciled with God (CD IV.2:654). The church is an event, a 'teleological direction in human history rather than an achieved embodiment of Christ' (Webster 2000:130). Barth's argument is that there is no gap between the then of Christ and the now. In such a way Barth's Christology and ecclesiology have direct meaning for ethics, spirituality and the way the Christian community is present in this world. To be church is to make Christ present in this world and requires the highest standards of ethical conduct, of integrity. The life of the church should correspond with the earthly life of Christ (Bender 2005:205).

Christ is never absent from the church. Christ is not made present by faith, preaching, sacraments or even miracles. Christ is present because He chooses to be present. Yet Christ is not physically present, which means He is present through the Holy Spirit (Bender 2005:195). The Holy Spirit is another form of the Parousia of Christ. In this way, Christ is at the same time present and not present in the church. On the one hand there is an immense difference between Christ and the church, whilst at the same time the church is organically one with Christ, the living body of Christ in this world.

If the church is the earthly-historical form of existence of the risen Lord Jesus Christ, the most powerful witness to the world is the fact that the church exists and functions as church. If we understand the essential nature of the church, 'being church' is a mind-boggling enterprise. If, like Barth, we believe that the church is 'in its visible being a witness to its invisible being' it has far-reaching implications (Healy 2008:115).

\section{Strategic perspective: Being church with integrity}

These few historical and hermeneutical remarks help us to realise just how much contemporary churches struggle with the question of integrity. Churches lose sight of the fundamental unity between Christ and his body. This has very direct consequences for the life of the church. The church is the body of Christ; it should also act and live and speak as the body of Christ.

Being church with integrity, being the body of Christ in everyday practice, is not a simple matter. Being church requires continual reformation and transformation. The question is: What are some of the practical implications? It is with some hesitation that I would suggest very briefly some factors the church needs to consider going forward. Obviously these need to be worked out further in a unique and specific way within various churches:

\section{A clear vision of the unity between Christ and his church}

One of the challenges facing churches is the growing disregard for the importance of the church within Christianity. It is not uncommon to hear expressions such as it is not about the church...', as if the church is of secondary importance and an optional extra in practising Christian faith. One is hesitant to generalise, but there is a growing tendency to dislocate Christian faith from the church, based on the assumption that you can be a Christian without the church. This view is not only taken by post-Christianity, but very often by members of the church. The church has become its own greatest enemy.

These kinds of views and perceptions depart from the assumption that the church is just a human organisation. If the church had been some human endeavour, cultural change agent or financial enterprise, it would be completely correct to regard the church as totally irrelevant, as a bunch of charlatans. Christianity and the world could get by without such a church.

But what does it really mean to be church? First of all, it requires a clear vision of the unity between Christ and the church, a clear understanding of the identity of the church which is to be found in Christ and not in man-made structures. Romans 6:1-14 reminds us of this unity with Christ. Baptism signifies a real unity between Christ and those who are baptised. The church is constituted by this unity. Unity with Christ is the essential nature of the church. Because all are united in Christ, there is only one church, although it may manifest visibly in diverse ways.

Part and parcel of this unity with Christ is the moral and ethical implications. The same passage in Paul's Letter to the Romans proclaims that we died with Christ and for that reason we are also dead to $\sin$. We should live as people who received a new life, a life of obedience, simplicity and authentic Christian values, to follow in the footsteps of Christ. This does not mean that we would ever be without sin, as Luther taught us with his dialectical principle of simul iustus, simul peccator. We will always remain justified sinners, but because of that we should become what we are in Christ, namely a holy people dedicated to God.

\section{Less institution, more 'church'}

By 1935, with the publication of Das Evangelium in Gegenwart, Barth was convinced that Christianity, as it established itself since the Edict of Milan, was irrevocably gone (Barth 1935:33; Busch 2004:242). The era of organic unity between church and state and a 'Christian society' has gone by. This is not a crisis, because Western culture and the Gospel of Jesus Christ are not identical (Barth 1935:23). The Gospel (Christianity, the church) is not dependent on political leaders or culture. The Gospel is free, and in this freedom it becomes powerful through the Holy Spirit. Through the Gospel and the work of the Spirit real faith becomes possible. The liberation of the Gospel from the chains of political and cultural control is not a disaster.

From this it is logical Barth would criticise the institutionalism of the church. Institutionalism is a form of disobedience, being unfaithful towards the Gospel, and will result in the destruction of the church and 'so-called Christianity' (Busch 2004:243). In 
his exposition of the Apostles' Creed (1936:121-122), Barth argues that church organisation and administration are of secondary importance. The institutional forms are secondary to the congregational life which happens in the midst of our earthly and historical existence (Koffeman 2014:88). We must accustom ourselves to the idea that it might be better for the preaching of the Gospel if the church would exist as a 'mall group of aliens and a mobile brotherhood' (CD IV/4:168).

\section{Missio Dei}

Barth brought a correction to the limited ecclesiology of the Reformation (Busch 2004:242), especially the reformed churches' lack of missionary vision. He comes to the conclusion that the only real reason for the church's existence is to be found in the Great Commission, to witness to the world of a reconciling God (Busch 2004:262).

It is now generally accepted that the concept of what is today known as missio Dei can be traced to a paper Barth delivered at the Brandenburg Mission Conference (1932), stating that mission was not primarily the work of the church, but of God himself. This view grew in popularity until, by the conclusion of the 1952 Willingen conference of the International Missionary Council, it was recognised that 'the missionary obligation of which we are a part has its source in the Triune God Himself' (see Bentley 2009; Bevans \& Schroeder 2004:290). This understanding of the missio Dei offers the language and tools to not only remain faithful to what the church is, but also to transform the congregational praxis, and could form the ecclesiological basis of reformed church polity and church order. Under Barth's influence the conviction grew that church law should be conceived and developed in terms of the mission of the church. Scripture, the confessions of faith, the nature of the church and mission became constitutive elements in church law (Reuver 2000:4).

\section{Being brave}

Barth once wrote that the church always 'becomes courageous thirty years too late' (Barth 1928:102). He was adamant that the church should not be trapped by its traditions or understanding of itself. The church must learn to listen to the voice of God who confronts us with the question: What are you doing to my church? (CD IV /1:692). Gerben Heitink, in his introduction to Een kerk met karakter, comes to the conclusion that the church of the 21st century has lost 'character' and is in dire need of radical transformation (Heitink 2007:21). By 'character' Heitink understands not only the nature or character of the church, but rather a church with the inherent conviction that its message is still relevant to the word and is brave enough to encounter the world in strange places.

\section{Ethical behaviour}

Leo Koffeman (2014) writes:

A church may be expected to require from its members, and particularly from those who bear representative or ministerial responsibilities, that they meet the highest standards of ethical behaviour. If not, it cannot acquire any moral authority in society. A church that tolerates injustice in its internal life, or who is not characterized by deep respect for human dignity in its external relationships, lacks all credibility. A congregation that does not first of all show reliability fails in a fundamental way. (p. 215)

A church with integrity does things in a certain way. Jesus taught us to love one another. Jesus touched people and cared for them. Augustine taught his church: Proclaim the Gospel of Jesus Christ, and if necessary use words ...

Against the background of a global economic crisis, the widening gap between rich and poor, corruption, the collapse of major economic systems, the ecological crisis and the misuse of natural resources, churches need to re-evaluate their commitment to social justice and to the alleviation of suffering. Concern for social and economic justice and the welfare of others, is a fundamental part of being church.

\section{Listen to the word}

A church with integrity listens to the Word of God. Under the guidance of the Holy Spirit, the church needs to discern the will of God. In the introduction of John Calvin's Commentary on the Psalms, he describes it as a 'conversio subita ad docelitam, a conversion to a teachable frame of mind' ... (Calvin 1557:23). Conversion requires discernment; the ability to listen, learn and live with your ear close to the mouth of the Lord Jesus. Conversion (and the reformation of the church) implies discipleship, following in the footsteps of Christ. Listening, learning and doing what we are taught is a life of integrity, a life in fullness (Mt 7:24-29). A church which listens, can truly reform.

\section{Language}

A church with integrity speaks a certain language. It gives expression to its own identity in words and deeds. It facilitates the transformation from an institutional, inward-living church to a church which has the vitality, energy and conviction to proclaim Jesus Christ as Lord and Saviour. Brueggemann pointed out that it is of utmost importance for the church to develop new modes of speech, in fact a new vocabulary. Christian faith needs to be articulated in new and creative ways. New metaphors are essential to reach a new generation with the Gospel (Brueggemann 1989:3). In this he follows H-G Gadamer whose understanding of language indicates a direct relation between the future and the way language is used and how people create identity through language (Gadamer 1977:259). New language facilitates transformation on a very deep level.

In his novel with the title 1984, George Orwell formulates the concept of 'Newspeak' by which he exposes the power of language. Language can be used negatively or positively, to control or manipulate or to set free. Hope is destroyed by reducing the vocabulary of hope. Orwell (1949) writes prophetically:

By 2003, earlier probably, all real knowledge of Oldspeak will have disappeared. The whole literature of the past will have been destroyed. Chaucer, Shakespeare, Milton, Byron - they'll 
only exist in Newspeak versions, not merely changed into something different, but actually contradictory of what they used to be. Even the literature of the Party will change. Even the slogans will change. How could you have a slogan like 'freedom is slavery' when the concept of freedom has been abolished? The whole climate of thought will be different. In fact, there will be no thought, as we understand it now. Orthodoxy means not thinking not needing to think. Orthodoxy is unconsciousness. (p. 253)

\section{Inclusivity}

A church with integrity includes people. Jesus included people in his circle (Koffeman 2014:149-168; Niemandt 2007:92), even those regarded by others as unclean and considered as unimportant. In the past, due to their dominant system story, reformed churches were regarded as exclusive religious communities. Quite to the contrary someone like John Calvin (following St. Augustine) wrote 'there are a lot of sheep outside the church, and many wolves within the church ...' (Calvin 1559:17). The church should not attempt to distinguish between true and false believers; who should be included or excluded from the church; who are welcome and who not (Calvin 1559:22-23). The church consists of sinners. As such people cannot be excluded from the church on the basis of perceived sin or social unacceptability. In South Africa this is of particular importance in light of racial divisions that still pervades our society.

\section{Conclusion}

Wherever there is a lack of theological depth in our ecclesiology, it leads to poor governance, a deathly silence on injustice, tolerance of corruption, materialism and a general loss of integrity and credibility. The easy way out is to accept that the empirical church is imperfect and that someday, when the Lord returns, we (the church) will be made perfect. If this is our view, it results in poor governance, laziness, incompetence and disregard of social responsibility - a church without integrity. Without integrity, all the beautiful words the church preaches, proclaiming the kingdom of God, will keep falling on sceptical ears.

The church is holy and apostolic, called to live a missional life characterised by integrity. The church, in Barth's words, is called to be church - not some charlatan organisation which recklessly endangers people's lives or falls into the trap of materialism. Living with integrity is not done for personal gain but the result of obedience to God and careful listening to what Jesus Christ taught us.

\section{Acknowledgements Competing interests}

The author declares that he has no financial or personal relationships which may have inappropriately influenced him in writing this article.

\section{References}

Altaner, B., 1951, Patrologie. Leben, Schriften und Lehre der Kirchenväter, Verlag Herder, Freiburg.

Barth, K., 1928, Die Theologie und die Kirche, Chr. Kaizer Verlag, München.
Barth, K., 1933, 'Für die Freiheit des Evangeliums', in Theologische Existenz Heute, Heft 2, Chr. Kaizer Verlag, München.

Barth, K., 1935, 'Das Evangelium in der Gegenwart', in Theologische Existenz Heute, Heft 25, pp. 18-36, Chr. Kaizer Verlag, München.

Barth, K., 1936, Credo, Chr. Kaizer Verlag, München.

Barth, K., 1956-1975, Church Dogmatics, Vols. I-XIII, revised edition, transl. G.T. Thomson \& H. Knight, and G.W. Bromiley \& T.F. Torrance (eds.), T \& T Clark, Edinburgh.

Bender, K.J., 2005, Karl Barth's Christological ecclesiology, Ashgate Publishing Limited, Burlington, VT.

Bentley, W., 2009, 'Karl Barth's understanding of mission: The Church in relationship', Verbum et Ecclesia 30(1), 25-49. http://dx.doi.org/10.4102/ve. v30i1.62

Bevans, S.B. \& Schroeder, R.P., 2004, Constants in context: A theology of mission for today, Orbis, Maryknoll, NY.

Boyd, G.A., 2005, The myth of a Christian nation. How the quest for political power is destroying the church, Zondervan, Grand Rapids, MI.

Brueggemann, W., 1989, Finally comes the poet: Daring speech for proclamation, Fortress, Minneapolis, MN.

Busch, E., 1998, Die Grosse Leidenschaft. Einführung in die Theologie Karl Barths, Chr. Kaiser Gütersloher Verlaghaus, Gütersloh.

Busch, E., 2004, The great passion. An introduction to Karl Barth's theology, transl. G.W. Bromley and D.L. Guder \& B. William (eds.), Eerdmans Publishing Company, Grand Rapids, MI.

Calvin, J., 1557 [1845], Commentary on the book of psalms, Volume 1, transl. J. Anderson, (1845) and published June 2005, Christian Classics Ethereal Library, Grand Rapids, Ml, viewed from http://www.ccel.org/ccel/calvin/ Library, Grand
calcom08.html

Calvin, J., 1559, Institutie of onderwijzing in de Christelijke godsdienst, transl. A. Sizoo, Naamloze Vennootschap W.D. Meinema, Delft.

Chernick, I., 2015, 'Fake "snake-eat" pastors to face scrutiny', Pretoria News, Friday, 21 August 2015, p. 1.

Dreyer, W.A., 2011, 'Praktiese ekklesiologie en bedieningspraktyk met verwysing na die Ned. Hervormde Kerk van Afrika', PhD proefskrif, Fakulteit Teologie, Universiteit van Pretoria, bl. 93-108.

Dreyer, W.A., 2012, 'The amazing growth of the early church', HTS Teologiese Studies/ Theological Studies 68(1), Art. \#1268, 7 pages, http://dx.doi.org/10.4102/hts. v68i1.1268

Du Toit, A.B., 2012, 'Sensitivity towards the reaction of outsiders as ethical motivation in early Christian paraenesis', HTS Teologiese Studies/Theological Studies 68(1), Art. \#1212, 7 pages. http://dx.doi.org/10.4102/hts.v68i1.1212

Faith \& Order, 1990, Church and world. The unity of the church and the renewal of human community, Faith \& Order Paper No. 151, WCC Publications, Geneva.

Faith \& Order, 2005, The nature and mission of the church, WCC Publications, Geneva.

Gadamer, H.-G., 1977, Man and language, in philosophical hermeneutics, transl. D.E. Linge, University of California Press, Berkeley, pp. 255-265.

Goold, G.P. \& Lake, K., 1975, The apostolic fathers, vol. 1 \& 2, transl. K. Lake and Original texts G.P. Goold (ed.), Harvard University Press, Cambridge, MA.

Healy, N.M., 2008, 'The church in modern theology', in G. Mannion \& L.S. Mudge (eds.), The Routledge companion to the Christian Church, pp. 106-126, Routledge, New York, NY.

Heitink, G., 2007, Een kerk met karakter. Tijd voor heroriëntatie, Uitgeverij Kok, Kampen.

Kinnaman, D., 2007, unChristian. What a new generation really thinks about Chritianity, Baker Books, Grand Rapids, MI.

Koffeman, L.J., 2014, In order to serve. An ecumenical introduction to Church Polity, Lit Verlag Dr. W. Hopf, Berlin.

Kotze, A., 2013, 'Cui narro haec? Augustine and his Manichaean audience: A re-reading of the first three books of the Confessions', HTS Teologiese Studies/ Theological Studies 69(1), Art. \#1357, 8 pages. http://dx.doi.org/10.4102/hts. v69i1.1357

Küng, H., 1968, The Church, Search Press, London.

Lodberg, P., 1995, 'The history of ecumenoical work on ecclesiology and ethics', The Ecumenical Review 47(2), 128-139. http://dx.doi.org/10.1111/j.1758-6623.1995. tb03690.x

Louw, J.P. \& Nida, E.A., 1989, Greek-English lexicon of the New Testament based on semantic domains, vol. 1, Bible Society of South Africa, Cape Town.

Nel, M., 2010, 'Missionale integriteit en kontekstuele relevansie', HTS Teologiese Studies/Theological Studies 67(3), 88-97. http://dx.doi.org/10.4102/ hts.v67i3.1084

Niemandt, N., 2007, Nuwe drome in nuwe werklikhede. Geloofsgemeenskappe in pas met ' $n$ postmoderne wêreld, Lux Verbi BM, Wellington.

Orwell, G., 1949, 1984, Penguin Books, London.

Pauw, J.M., 2012, 'Clemens I van Rome', viewed 22 April 2013, from http://www. jmpauw.nl/33-kerkgeschiedenis/apostolische-vaders/236-clemens 
Rah, S.-C., 2009, The next evangelicalism. Freeing the church from Western cultural captivity, InterVarsity Press, Downers Grove, IL.

Randi, J., 1987, The faith healers, Prometheus Books, Buffalo, NY.

Reuver, M., 2000, Faith and law. Juridical perspectives for the ecumenical movement, WCC Publications, Geneva.

Schor, A.M., 2009, 'Conversion by the numbers: Benefits and pitfalls of quantitative modelling in the study of early Christian growth', Journal of Religious History 33(4), 472-498. http://dx.doi.org/10.1111/j.1467-9809.2009.00826.x
Viola, F. \& Barna, G., 2008, Pagan Christianity? Exploring the roots of our church practises, Tyndale House Publishers, Carol Stream, IL.

Webster, J., 2000, Barth, Continuum, London.

World Alliance of Reformed Churches, 2010, Europe covenanting for justice, M. Wasserloos-Strunk (ed.), Foedus Verlag, Wuppertal.

World Council of Churches, 2013, 'Together towards life: Mission and evangelism in changing landscapes', in World Council of Churches Resource Book (10th Assembly Busan 2013), WCC Publications, Geneva. 